\title{
Who is the happy warrior? Philosophy, happiness research, and public policy
}

\author{
Martha C. Nussbaum
}

Received: 5 November 2011/Accepted: 7 February 2012/Published online: 23 October 2012

(C) Springer-Verlag 2012

Who is the happy warrior? Who is he.

That every man in arms should wish to be?

Wordsworth, Character of the Happy Warrior.

Man does not strive after happiness; only the Englishman does that.

Nietzsche, Maxims and Arrows.

Psychology has recently focused attention on subjective states of pleasure, satisfaction, and what is called "happiness." The suggestion has been made in some quarters that a study of these subjective states has important implications for public policy. Sometimes, as in the case of Martin Seligman's "positive psychology" movement, attempts are made to link the empirical findings and the related normative judgments directly to the descriptive and normative insights of ancient Greek ethics and modern virtue ethics. At other times, as with Daniel Kahneman's work, the connection to Aristotle and other ancient Greek thinkers is only indirect, and the connection to British Utilitarianism is paramount; nonetheless, judgments are made that could be illuminated by an examination of the rich philosophical tradition that runs from Aristotle through to J. S. Mill's criticisms of Bentham.

This paper is a revised and updated version of a paper entitled "Who is the Happy Warrior? Philosophy Poses Questions to Psychology," which appeared in Law and Happiness, edited by Eric A. Posner and Cass R. Sunstein, Chicago: University of Chicago Press, 2010, pp. 81-114. I am grateful to Eric Posner for guidance, comments, and suggestions, to all the participants in a conference on happiness in spring 2007 for their helpful input, and to an anonymous referee. I am grateful to Luigino Bruni and Pier Luigi Porta for inviting me to a conference on happiness in Milan in June, 2011, and for their suggestions for revision.

M. C. Nussbaum $(\bowtie)$

Ernst Freund Distinguished Service Professor of Law and Ethics, Law School and Philosophy Department, The University of Chicago, Chicago, IL, USA

e-mail: martha_nussbaum@law.uchicago.edu 
The aim of my paper is to confront this increasingly influential movement within psychology with a range of questions from the side of philosophy. Often these questions have a very long history in the discipline, going back at least to Aristotle; the more thoughtful Utilitarians, above all Mill, also studied them in depth. Some of these questions are conceptual; others are normative. After going through quite a number of them, I will attempt to correct some misunderstandings, within this psychological literature, of my own "objective-list" conception and the role I think it ought to play in public policy. And I will say what I think some appropriate roles for subjective-state analysis in public policy might be.

\section{Conceptual issues}

\subsection{What is pleasure?}

Psychologists often talk about pleasure and also about subjects' hedonic state. Too rarely, however, do they ask some very obvious questions about it that greatly affect any research program involving the concept. Two central questions are as follows: Is pleasure a single thing, varying only in intensity or duration, or Is it plural, containing qualitative differences? And, is it a sensation, or is it something more like a way of attending to the world, or even a way of being active?

Jeremy Bentham famously held that pleasure was a single sensation, varying only along the quantitative dimensions of intensity and duration. ${ }^{1}$ Modern psychology follows Bentham. Indeed, Kahneman explicitly traces his own conception of "hedonic flow" to Bentham. ${ }^{2}$ And yet, Is Bentham correct? Does his account correctly capture the complexity of our experience of pleasures of many sorts? We speak of pleasure as a type of experience, but we also refer to activities as "my pleasures," saying things like, "My greatest pleasures are listening to Mahler and eating salmon." We also use verbal locutions, such as "enjoying" and "taking delight in." (The ancient Greeks used such verbal locutions much more frequently than they used the noun.) Such ways of talking raise two questions as follows: Is pleasure a sensation at all, if such very different experiences count as pleasures? And is it single? Could there be any one thing that both eating a nice piece of salmon and listening to Mahler's Tenth, that harrowing confrontation with grief and emptiness, have in common?

These questions were subtly discussed by Plato, Aristotle, and a whole line of subsequent philosophers. ${ }^{3}$ Bentham simply ignores them. As Mill writes in his great

\footnotetext{
1 See my discussion in "Mill Between Bentham and Aristotle," Daedalus Spring 2004: 60-68. Reprinted in Economics and Happiness, ed. Luigino Bruni and Pier Luigi Porta (Oxford: Oxford University Press, 2005), 170-183.

2 See, for example, Daniel Kahneman and Alan B. Krueger, "Developments in the Measurement of Subjective Well-Being," Journal of Eocnomic Perspectives 20 (2006), 3-24, at p. 4. In reality, however, Kahneman's conception is simpler than Bentham's, since it focuses on momentary experience and omits "duration."

3 For one good philosophical overview, see J. C. B. Gosling and C. C. W. Taylor, The Greeks on Pleasure (Oxford and New York: Clarendon Press, 1982); see also the excellent treatment in Taylor's Plato: Protagoras (Oxford: Clarendon Press, 1976). An admirable general philosophical discussion is J. C. B. Gosling, Pleasure and Desire (Oxford: Clarendon Press, 1969).
} 
essay "On Bentham," "Bentham failed in deriving light from other minds." For him, pleasure simply must be a single homogeneous sensation, containing no qualitative differences. The only variations in pleasure are quantitative. Pleasures can vary in intensity, duration, certainty or uncertainty, propinquity or remoteness, and, finally, in causal properties (tendency to produce more pleasure, etc.). The apparent fact that pleasures differ in quality that the pleasure of salmon-eating is quite different from the pleasure of listening to Mahler's Tenth bothered Bentham not at all; he does not discuss such examples.

Perhaps the reason for this problem is that Bentham's deepest concern is with pain and suffering, and it is somewhat more plausible to think of pain as a unitary sensation varying only in intensity and duration. Even here, however, qualitative differences seem crucial: The pain of a headache is very different from the pain of losing a loved one to death. Perhaps, it is because Bentham is far more concerned with bodily pain than with emotional distress that he fails to discuss this problem.

As Mill says, Bentham's view expresses "the empiricism of one who has had little experience" - either external, he adds, or internal, through the imagination.

Nor was Bentham worried about interpersonal comparisons, a problem on which economists in the Utilitarian tradition have spent great labor, and one that any program to use subjective satisfaction for public policy must face. For Bentham, there was no such problem. When we move from one person to many people, we just add a new dimension of quantity. Right action is ultimately defined as that which produces the greatest pleasure for the greatest number. Moreover, Bentham sees no problem in extending the comparison class to the entire world of sentient animals. One of the most attractive aspects of his thought is its great compassion for the suffering of animals, which he took to be unproblematically comparable to human suffering. ${ }^{4}$ This attractive aspect, however, is marred by his failure even to consider whether animal pains and pleasures are qualitatively different, in at least some respects, from human pains and pleasures.

What is appealing about Bentham's program is its focus on urgent needs of sentient beings for relief from bodily suffering and its determination to take all suffering of all sentient beings into account. But Bentham cannot be said to have developed anything like a convincing account of pleasure and pain, far less of happiness. Because of his attachment to a strident simplicity, the view remains a sketch crying out for adequate philosophical development.

Modern philosophers starting off from the Greco-Roman tradition have noticed that already in that tradition there is a widespread sense that Bentham's sort of answer will not do. A proto-Benthamite answer is familiar, in views of hedonists such as Eudoxus 5 and the title character in Plato's Philebus, who represented Eudoxus's position. But there is an equally widespread sense among the Greek thinkers that this view will not do. The young interlocutor Protarchus, in the Philebus, is quickly brought by Socrates to reject it: He sees that the sources of

\footnotetext{
${ }^{4}$ He denied that animals suffered at the very thought of death, and thus he argued that the painless killing of an animal is sometimes permitted.

${ }^{5}$ No writings of Eudoxus survive; we know his views through Aristotle's characterization of them in Nicomachean Ethics 1172b 9 ff., and by reports of later doxographers; he is usually taken to be the inspiration for the title character in Plato's Philebus.
} 
pleasure color the pleasure itself and that the pleasure of philosophizing is just not the same qualitatively as the pleasure of eating and sex. (The name "Philebus" means "lover of young men," and the character is represented as using his unitary view of pleasure to seduce attractive youths. $)^{6}$

Aristotle takes up where the Philebus left off. Throughout his work, he insists on the tremendous importance of qualitative distinctions among the diverse constituent parts of human life; he later suggests that these distinctions affect the proper analysis of the concept of pleasure. Notoriously, however, he offers two very different conceptions of pleasure, one in book VII and one in book X of the Nicomachean Ethics. The first identifies pleasure with unimpeded activity (not so odd if we remember that we speak of "my pleasures" and "enjoyments"). The second, and probably better, account holds that pleasure is something that comes along with, supervenes on, activity, "like the bloom on the cheek of a young person." In other words, it is so closely linked to the relevant activities that it cannot be pursued on its own, any more than bloom can be adequately cultivated by cosmetics. To get that bloom, you have to pursue health. Similarly, one gets the pleasure associated with an activity by doing that activity in a certain way, apparently a way that is not impeded or is complete. It would seem that what Aristotle has in mind is that pleasure is a kind of awareness of one's own activity, varying in quality with the activity to which it is so closely linked. In any case, pleasure is not a single thing, varying only in intensity and duration (the Eudoxan position). It contains qualitative differences, related to the differences of the activities to which it attaches.

J. S. Mill follows Aristotle. In a crucial discussion in Utilitarianism, he insists that "[n]either pains nor pleasures are homogenous." There are differences "in kind, apart from the question of intensity," that are evident to any competent judge. We cannot avoid recognizing qualitative differences, particularly between "higher" and "lower" pleasures. How, then, to judge between them? Like Plato in Republic book IX, Mill refers the choice to a competent judge who has experienced both alternatives.

This famous passage shows Mill thinking of pleasures as very like activities (with Aristotle in Book VII) or, with Aristotle in Book X, as experiences so closely linked to activities that they cannot be pursued apart from them. In a later text, he counts music, virtue, and health as major pleasures. Elsewhere, he shows that he has not left sensation utterly out of account: He refers to "which of two modes of existence is the most grateful to the feelings." Clearly, however, the unity of the Benthamite calculus has been thrown out, to be replaced by a variegated conception, involving both sensation and activity, and prominently including qualitative distinctions. It is for this reason that philosophers today typically find Mill more subtle and conceptually satisfactory than Bentham.

Modern philosophical discussion of pleasure follows Aristotle and Mill. In one of the best recent accounts, J. C. B. Gosling's book Pleasure and Desire, ${ }^{7}$ Gosling

\footnotetext{
${ }^{6}$ In the Greek world, this would not mark him as depraved, only as greedy: he's the Greek equivalent of a "womanizer."

7 Above n. 4.
} 
investigates three different views of what pleasure is: the sensation view (Bentham/ Eudoxus); the activity view (Aristotle's first account); and what he calls the "adverbial" view (pleasure is a particular way of being active, a view closely related to Aristotle's second account). Uneasily, with much uncertainty, he opts, with Aristotle, for the adverbial view.

Now, it is obvious that such debates influence the ways in which one would study pleasure empirically. If Aristotle, Mill, and Gosling are correct, it would not make sense to ask people to rank all their pleasures along a single quantitative dimension: This is just bullying people into disregarding features of their own experience that reflection would quickly reveal. People are easily bullied, particularly by prominent psychologists, and so they do answer such questions, rather than responding, "This question is ill-formed." (This docility is probably related to the general subservience to scientific authority that Stanley Milgram's experiments so disturbingly demonstrate.) If Mill and Aristotle are right, however, they would quickly agree on reflection that qualitative differences matter.

Moreover, any experiment that simply assumes pleasure to be a hedonic state, something like a sensation, would also be inadequate, say Mill and Aristotle, to the complexity of human experience, since people agree that activity matters: They would not think-and do not think - that the pleasure derived from being plugged into Robert Nozick's “experience machine" was equivalent to a pleasure associated with actually doing the activity oneself. ${ }^{8}$

\subsection{What is satisfaction with one's life as a whole?}

Some of the most influential experiments ask not about pleasure or hedonic flow, but about satisfaction with one's life as a whole. Typical is the question posed by Kahneman, "Taking all things together, how satisfied are you with your life as a whole these days? Are you very satisfied, satisfied, not very satisfied, not at all satisfied?"9 Notice here the bullying we encountered before: People are simply told that they are to aggregate experiences of many different kinds into a single whole, and the authority of the questioner is put behind that aggregation. There is no opportunity for them to answer something plausible, such as "Well, my health is good, and my work is going well, but I am very upset about the state of the economy, and one of my friends is very ill." Not only is that opportunity not provided, but, in addition, the prestige of science-indeed of the Nobel Prize itself - is put behind the instruction to reckon all life-elements up as a single whole. The fact that people answer such questions hardly shows that this is the way that they experience their lives.

If we bracket that difficulty, however, we arrive at another one. There is a deep ambiguity about the question being asked. The psychologists who pose this question take the question to be a request for a report of a subjective state of satisfaction, which is at least closely akin to the feeling of pleasure. (Kahneman treats this question and the hedonic-flow question, on the whole, as different ways of getting at

\footnotetext{
8 See Robert Nozick, Anarchy, State, and Utopia (New York: Basic Books, 1974), 42-45.

9 Kahnemann and Krueger, p. 7 n. 2, emphasis in the original.
} 
the same thing.) One might indeed hear the question that way. But one might also hear it in a very different way, as a request for a reflective judgment about one's life, which judgment might or might not be accompanied by feelings of satisfaction, contentment, or pleasure.

Consider J. S. Mill's last words: "You know that I have done my work." ${ }^{10}$ I would say that this is in one way an answer to the overall-satisfaction question: Mill is reporting, we might say, satisfaction with his life as a whole. He has done what he aimed to do. And yet it seems highly unlikely that Mill, on his deathbed, suffering from physical pain and from the fear of death that he acknowledges not being able to get rid of, is experiencing feelings of satisfaction or pleasure. (Mill once reports that the one great attraction of a belief in a life after death-which he finds himself ultimately unable to accept-is the hope it yields of being reunited "with those dear to him who have ended their earthly life before him"-a loss, he continues, that "is neither to be denied nor extenuated." deathbed, with the eternal loss of Harriet in addition to his own demise.) While judging that his life has been on balance successful, he is almost certainly not experiencing feelings of satisfaction or pleasure.

Since the psychologists who work with this question do not notice this ambiguity, they do nothing to sort things out, so we do not really know which question their subjects are answering. Probably some are answering one question, some the other. What would be needed to progress would be conceptual work to separate the feeling-conception from the judgment-conception and then a set of questions designed to tease apart those distinct notions.

In my own case, the ambiguity produces something like a contradiction. That is, my own conception of a good life attaches a great deal of value to striving, longing, and working for a difficult goal. So, if I ever notice myself feeling feelings of satisfaction, I blame myself and think that, insofar as I have those feelings, I'm like Mill's "pig satisfied" or Aristotle's "dumb grazing animals," and thus, reflectively, I report dissatisfaction with my life as a whole. Nor do I think that I am an unusual case. As I've indicated, Mill's contrast between Socrates and the pig reveals similar values, and anyone whose culture is deeply influenced by romanticism, with its exaltation of longing and yearning (or, indeed, by the more romantic varieties of Christianity, such as Augustine's), would have the same difficulty: Insofar as one is feeling satisfied, thus far one's life is not a success. That is what Nietzsche is getting at in my epigraph: Having feelings of satisfaction as a goal, he thinks, is a rather base thing, something that he associates with the impoverishment of English culture, as contrasted with German romanticism. Zarathustra, asked whether he is happy, responds, "Do I strive after happiness? I strive after my works." 12 Schiller, Beethoven, and Mahler might have said that they were satisfied with their life as a whole-in the reflective-judgment sense. They probably, however, did not report

\footnotetext{
${ }^{10}$ See Michael St. John Packe, The Life of John Stuart Mill (New York: Macmillan, 1954), p. 507.

11 See the late essay, "The Utility of Religion," in Mill: Three Essays on Religion (Amherst, N. Y.: Prometheus Books, 1998), 69-122, at 120.

12 See the excellent treatment of this passage in Henri Birault, "Beatitude in Nietzsche," in The New Nietzsche, ed. David Allison (Cambridge, MA: MIT Press, 1985), 219-231.
} 
many feelings of satisfaction, and they would have worried about themselves if they had had such feelings. (Indeed, Mahler's Resurrection Symphony revolves precisely around the contrast between the herdlike feeling of satisfaction and the more exalted judgment that one's whole life is rich and meaningful-because it is governed by an active kind of love. The former is represented by the swoopy, aimless clarinet phrases of the third movement and the latter by the passionate heartbeat that the final movement associates with the wings of the soul. ${ }^{13}$ )

\subsection{What is happiness?}

Bentham simply identifies happiness with pleasure. Kahneman on the whole agrees with Bentham. Some psychologists are more subtle. Seligman's conception of authentic happiness, for example, involves both positive emotion and valuable activity. ${ }^{14}$ But (to return to my question about Socrates and the pig), how are these two constituents related? Are they both necessary for happiness and jointly sufficient? Is one more important than the other? And must the positive emotion be suitably linked to the good activity, a kind of taking delight in one's good activity?

Here is what Aristotle thought: that activity is far and away the main thing and that pleasure will normally crop up in connection with doing good activities without struggle, the way a virtuous person does them. Pleasure accompanies activity and completes it, like, he says, the bloom on the cheek of a healthy young person. That example implies, too, that it would be totally mistaken to pry the pleasure apart from the activity and seek it on its own: for it would then not be the bloom on the cheek of a healthy person, it would be the rouge on the cheek of a person who has not bothered to cultivate health. And Aristotle also thought that sometimes the pleasure will not arrive: For example, the courageous person who is about to lose his life in battle is happy, but has no pleasant emotion, because he is losing everything. Wordsworth's very Aristotelian poem, "Character of the Happy Warrior," tells a similar tale, describing the "happy warrior" as "happy" because he is active in accordance with all the virtues; and yet he has little if any pleasure and a good deal of pain. ${ }^{15}$

Wordsworth is a useful interlocutor at this point, because we can see that the Aristotelian conception of happiness was dominant until Bentham's influence dislodged it, changing the very way that many people, at least, hear the English word "happiness." So powerful was the obscuring power of Bentham's oversimplification that a question that Wordsworth takes to be altogether askable, and which, indeed, he spends eighty-five lines answering - the question what happiness really is-soon looks to philosophers under Bentham's influence like a question whose answer is so obvious that it cannot be asked in earnest. Thus, early twentiethcentury philosopher Henry Prichard, albeit a foe of Utilitarianism, was so influenced

\footnotetext{
13 See my analysis of the symphony in Upheavals of Thought: The Intelligence of Emotions (New York: Cambridge University Press, 2001).

14 Seligman, Authentic Happiness: Using the New Positive Psychology to Realize Your Potential for Lasting Fulfillment (New York: The Free Press, 2002).

15 The complete text of the poem can be found in "Appendix 1."
} 
in his thinking about happiness by Bentham's conception that he simply assumed that any philosopher who talks about happiness must be identifying it with pleasure or satisfaction. When Aristotle asks what happiness is, Prichard argued, he cannot really be asking the question he appears to be asking, since the answer to that question is obvious: happiness is contentment or satisfaction. Instead of asking what happiness consists in, then, he must really be asking about the instrumental means to the production of happiness. ${ }^{16}$ Nietzsche, similarly, understands happiness to be (uncontroversially) a state of pleasure and contentment and expresses his scorn for Englishmen who pursue that goal, rather than richer goals involving suffering for a noble end, continued striving, activities that put contentment at risk, and so forth. Apparently unaware of the richer English tradition about happiness represented in Wordsworth's poem, he simply took English "happiness" to be what Bentham said it was. So, much later, did Finnish sociologist Erik Allardt, when he wrote an attack on the idea that happiness was the end of social planning, entitling his book Having, Loving, Being - active things that he took to be more important than satisfaction, which Finns, heir of Nordic romanticism, typically think quite unimportant. ${ }^{17}$ Like Nietzsche, he understood the "happiness" of the social scientists to be a state of pleasure or satisfaction. (He is correct about the social scientists, if not about "happiness.")

Aristotle's richer conception is still present in our lives, and we can see that ideas like Seligman's idea of authentic happiness capture something of its spirit. ${ }^{18}$ According to this Aristotelian tradition, what we all can agree about is that happiness (eudaimonia) is something like flourishing human living, a kind of living that is active, inclusive of all that has intrinsic value, and complete, meaning lacking in nothing that would make it richer or better. Everything else about happiness is disputed, says Aristotle, but he then goes on to argue for a conception of happiness that identifies it with a specific plurality of valuable activities, including activity in accordance with excellences $^{19}$ (valuable traits) of many sorts, including ethical, intellectual, and political excellences, and activities involved in love and friendship. Pleasure, as I have said, is not identical with happiness, but it usually (not always) accompanies the unimpeded performance of the activities that constitute happiness.

\footnotetext{
${ }^{16}$ H. A. Prichard, "The Meaning of agathon in the Ethics of Aristotle," Philosophy 10 (1935) 27-39, famously discussed and criticized in J. L. Austin, "Agathon and eudaimonia in the Ethics of Aristotle," in Austin, Philosophical Papers, ed. J. O. Urmson and G. J. Warnock (Oxford and New York: Oxford University Press, 1979), 1-31. My account of Prichard follows Austin's, including his (fair) account of Prichard's implicit premises.

17 Erik Allardt, Att ha, alska, att vara: Om valfard i Norden (Having, Loving, Being: On Welfare in the Nordic Countries (Borgholm: Argos, 1975. A brief summary of some of the argument in English can be found in Allardt, "Having, Loving, Being: An Alternative to the Swedish Model of Welfare Research," in The Quality of Life, ed. M. Nussbaum and A. Sen (Oxford: Clarendon Press, 1993), 88-94. (The original language of the book is Swedish because Allardt is a Swedish-speaking Finn.).

18 For an excellent recent analysis, arguing that the Aristotelian view captures best our intuitive sense of what happiness is, see Robert Nozick, The Examined Life (New York: Simon and Schuster, 1989), chapter 10 .

19 I thus render Greek aretê, usually translated "virtue." Aretê need not be ethical; indeed it need not even be a trait of a person. It is a trait of anything, whatever that thing is, that makes it good at doing what that sort of thing characteristically does. Thus Plato can speak of the aretê of a pruning knife.
} 
Something like this is the idea that Wordsworth is relying on, when he asks, in each of the many areas of life, what the character and demeanor of the "happy warrior" would be, and answers that question. As J. L. Austin memorably wrote in a devastating critique of Prichard on Aristotle, "I do not think Wordsworth meant ...: 'This is the warrior who feels pleased.' Indeed, he is 'Doomed to go in company with Pain/And fear and bloodshed, miserable train.",

As Austin saw, the important thing about the happy warrior is that he has traits that make him capable of performing all of life's many activities in an exemplary way, and he acts in accordance with those traits. He is moderate, kind, courageous, loving, a good friend, concerned for the community, honest, ${ }^{20}$ not excessively attached to honor or worldly ambition, a lover of reason, an equal lover of home and family. His life is happy because it is full and rich, even though it sometimes may involve pain and loss.

So, would Seligman agree with Aristotle and Wordsworth that the happy warrior is indeed happy? Or does he require pleasant emotion in addition to the good activity? If even Seligman's conception is underspecified, however, Kahneman does not get to the point of noticing a problem at all and simply goes along with Bentham.

(I note that the happy warrior is happy, even in painful battle, because he is still able to act well; Aristotle believed, however, that more extreme calamities could "dislodge" one from happiness, by removing one's sphere of activity. His example is Priam at the end of the Trojan War, who lost his children, his political freedom and power, and his personal freedom. ${ }^{21}$ )

When we notice that happiness is complex, we are prepared to face yet a further question in connection with its proper analysis as follows: Does happiness require self-examination? All the ancient philosophers take issue with some of the popular accounts of eudaimonia in their cultural setting, by arguing that no life is truly happy unless it is accompanied by reflection. As Socrates says in the Apology, "The unexamined life is not worth living for a human being." One sees clearly in Plato's dialogues how controversial this emphasis is. When people are asked to define a virtue (seen as a putative part of happiness), they never include this element of knowledge or reflection-until Socrates patiently shows them that any definition that leaves it out is inadequate. On reflection, however, they always agree with Socrates, and I'd say that my contemporary students do as well when they think about it for a while. Aristotle gives a little more room than Plato does to the nonintellectual elements in virtue, including emotions as at least one part of what each virtue involves. But he, too, sticks to the Socratic commitment, saying that each and every virtue of character requires the intellectual virtue of practical wisdom. Much later, as we saw, J. S. Mill insists that it is better to be Socrates dissatisfied than a pig satisfied.

\footnotetext{
${ }^{20}$ Here we see the one major departure from Aristotle that apparently seemed to Wordsworth required by British morality. Aristotle does not make much of honesty. In other respects, Wordsworth is remarkably close to Aristotle, whether he knew it or not.

21 See my treatment of this passage in The Fragility of Goodness: Luck and Ethics in Greek Tragedy and Philosophy (Cambridge: Cambridge University Press, updated edition 2001), chapter 10.
} 
Wordsworth, as you can see, agrees with the Socratic tradition: The happy warrior's "law is reason." He "depends/Upon that law as on the best of friends," and he strives to become ever "More skilful in self-knowledge."

The commitment to reflection is also a commitment to the ceaseless critical scrutiny of cultural beliefs and cultural authorities. Well in advance of modern psychological research on deference to authority (Milgram) and peer pressure (Asch), Socrates knows that these endemic human failings disable democratic life. Therefore, he interrogates everyone he meets, and nobody does very well, especially not received cultural authorities. Socrates himself does best only in the sense that he is aware of the incompleteness and fallibility of his knowledge of happiness. Although later Greek philosophers are more willing than Socrates to pronounce on what happiness is, they are no more trustful of their culture, and all are relentless critics of their cultures' dominant understandings of happiness. Aristotle excoriates the undue attention given to the accumulation of wealth, to pleasure, and to manly honor. The Stoics have similar criticisms. And yet, they hold, not implausibly, that if people give it enough thought, they will agree with their proposal, because it honors something that people will understand to be deep in themselves, the source of their human dignity.

The omission of this reflective element in happiness is one of the most disturbing aspects of the conceptual breeziness of contemporary subjective-state psychology, insofar as it is laying the groundwork for normative recommendations. Our democracy has many of the vices Socrates identified in his: haste, macho posturing, an excessive deference to wealth and honor. We badly need the element of reflection, and if prestigious psychologists simply tell us again and again that reflection is not a necessary element of the happy life, we may begin to believe it.

\subsection{What emotions are positive?}

The part of subjective-state measurement that focuses on moment-to-moment hedonic flow assumes that some emotions are "positive" and others are "negative." Seligman makes a similar assumption and tells us somewhat more about what he is assuming, in keeping with his rather greater interest in philosophical matters. For Seligman, positive emotions, to put it somewhat crudely, are those that feel good. So, love would be positive, anger and grief negative, and so forth.

The ancient thinkers adopt a very different account. Again, this issue deeply affects any normative recommendations that may ultimately be based on the conceptual assumptions.

Since the Greeks and Romans (along with the best work on emotions in contemporary cognitive psychology) believe that emotions embody appraisals or evaluations of things in the world, they think it is very important for those appraisals to be correct. Fear, for example, involves (in Aristotle's view) the thought that there are serious damages impending and that one is not entirely in control of warding them off. Anger (again in Aristotle's view) involves the thought that a serious and inappropriate damage has been willfully inflicted on me or someone or something one cares about, and also the thought that it would be good for that damage to be made good somehow. 
So, we can see that there are a number of things that can go wrong here. One might get the facts wrong, thinking that a danger was present when it was not or that a wrong had been done when it had not. One might blame the wrong person for the wrong or might wrongly believe that the damaged was blameworthy when it was in fact accidental. Finally, one can get the seriousness of the good or bad event wrong: One may get angry over trivia-Aristotle's example is when someone forgets your name, so you see the world has changed little. Or, again Aristotle's example, one might fear a mouse running across the floor.

Because emotions embody appraisals, one can only get them to be appropriate by getting appropriate appraisals. Thus, in the Rhetoric, Aristotle gives the aspiring orator recipes for provoking anger in an audience-by convincing them that their enemies have wronged them in some illicit way, for example-and also recipes for taking anger away and calming people down-by convincing them that they had not in fact been wronged in the way they thought or that the thing was not of much importance.

For all the ancient thinkers, a necessary and sufficient condition of an emotion's being truly positive-in the sense of making a positive contribution toward a flourishing life - is that it be based on true beliefs, both about value and about what events have occurred. This is as true of good-feeling as of bad-feeling emotion. Many instances of good-feeling emotion are actually quite negative, inasmuch as they are based on false beliefs about value. Pleasure is only as good as the thing one takes pleasure in: If one takes pleasure in harming others, that good-feeling emotion is very negative; even if one takes pleasure in shirking one's duty and lazing around, that is also quite negative. If one feels hope, that emotion is good only if it is based on accurate evaluations of the worth of what one hopes for and true beliefs about what is likely.

By the same token, many negative-feeling emotions are appropriate and even very valuable. Aristotle, like Wordsworth, stresses that the courageous person is not free from fear: Indeed, he will appropriately feel more fear and pain at the prospect of losing his life in battle than the mediocre person, because his life, which is at risk, is a valuable life and he knows it. Anger is a sign of what we care intensely about and a spur to justice. Aristotle does not urge people to be angry all the time; indeed, he thinks that the appropriate virtue in this area should be called "mildness of temper," in order to indicate that the good person does not get angry too often. But if someone did not get angry at damages to loved ones or kin, he would be "slavish," in Aristotle's view. Again, compassion is painful, but it is extremely valuable, when based on true beliefs and accurate evaluations of the seriousness of the other person's predicament, because it connects us to the suffering of others and gives us a motive to help them. Grief when a loved one dies is extremely appropriate (although Plato, admiring self-sufficiency, tried to deny this).

The ancient philosophers also stress that happy and sad emotions are conceptually interconnected: To the extent that you value uncertain things that are in the control of chance, you cannot help having both fear and hope about them, since their prospects are in fact uncertain. Where you have love, you will also have anxiety - and, very likely, anger. Where you have gratitude (when someone does something importantly nice for you), there is also conceptual space for anger (if that 
same person should decide to treat you badly). The Stoics saw clearly that the only way to get rid of painful emotions was not to value the uncertain things of human life at all and to care only for one's own inner states. But Aristotle and most modern readers of the texts reject that solution.

Aristotle is correct here. That is, emotions are positive or negative, in the sense relevant to normative thinking, according to the correctness of the appraisals or evaluations they contain. And since human life contains, in fact, many bad accidents and much bad behavior, there is no way a person who values friends, loved ones, work, and political action can avoid having many painful-feeling emotions, such as grief, fear, and anxiety. These emotions are valuable in themselves, as expressions of correct evaluation, and also spur to good action. Can one imagine a struggle for justice that was not fueled by justified anger? Can one imagine a decent society that is not held together by compassion for suffering? Can one imagine love that does not assume the risk of grief? C. Daniel Batson's excellent research on compassion (which, I note en passant, has a rare philosophical sophistication and precision) has shown that the painful emotion leads to helping; so, it is extremely important not to set out to avoid painful emotional experiences. ${ }^{22}$

Seligman, in particular, thinks that it is good to promote good-feeling emotions and to minimize bad-feeling emotions, often by thinking hopeful thoughts. But sometimes having a hopeful "take" on the bad thing that has happened seems to trivialize it. The Stoics urged people to respond to the death of a loved one with constructive sentiments, such as "Everyone is mortal, and you will get over this pretty soon." But are they correct? Is this really the way to take the measure of love? ${ }^{23}$ It is very interesting to see how Cicero, who in his voluminous correspondence consoled his friends with positive sentiments like Seligman's, rejects them utterly when his beloved daughter Tullia dies. Among the most moving letters in history are his outpourings of desperate grief to his friend Atticus, to whom he says that he feels that he is in a dark forest, and whose injunctions to put an end to his mourning he angrily rejects, saying that he cannot do it, and moreover, he thinks that he should not, even if he could. ${ }^{24}$

Today, Americans are often are embarrassed by deep grief and tend to give Stoic advice too freely. A colleague in my university lost his son: a young man, troubled, who died either of a drug overdose or by suicide. I wrote him saying that I thought this was the worst thing that could happen to someone and he had my sympathy. This man, whom I don't know very well, wrote back immediately, thanking me and saying, "I really dislike this American stuff about healing." (He is an American.) I inferred from that response that many other messages he had received had talked about healing, and he had gotten fed up with them. I'm with him: It seems a deeply inappropriate way to think of the tragic death of a child.

So, I'd like to see psychology think more about positive pain, that is, the grief that expresses love, the fear that expresses a true sense of a threat directed at

\footnotetext{
22 C. Daniel Batson, The Altruism Question (Hillsdale, N. J.: Lawrence Erlbaum, 1991) and Altruism in Humans (New York: Oxford Unversity Press, 2011).

23 See my longer reflections on this question in The Therapy of Desire: Theory and Practice in Hellenistic Ethics (Princeton: Princeton University Press, 1994), chapters 10 and 12.

24 See the excellent edition and translation of Cicero's letters by David Shackleton Bailey in the Loeb Classical Library; the relevant letters are in volume III of the Letters to Atticus.
} 
something or someone one loves, the compassion that shares the pain of a suffering person, the anger that says, "This is deeply wrong and I will try to right it."

\section{Normative questions}

I have suggested, along with Aristotle and Mill, that the Benthamite conception does not adequately capture our concepts of pleasure and happiness, nor does the focus on overall life-satisfaction have the conceptual clarity that is imputed to it. However, Benthamism captures something, whether or not that something is coincident with our reflective concepts of pleasure and happiness, so let us now ask whether that something is a good guide to public policy. Should public policy focus on promoting pleasant feelings and minimizing painful feelings? I have already suggested some reasons for doubt in the preceding section, but let us go through the reasons more systematically.

\subsection{Bad pleasures, good pains}

Let us stipulate for the sake of argument that Bentham is correct: Pleasure is a single uniform sensation, even if it is produced by activities and objects of many different kinds. Nonetheless, it still seems problematic to conclude, as Bentham quickly does, that pleasure is the single thing that we should be aiming to produce. First of all, even if pleasure were single and homogeneous, a good life for a human being clearly is not single: As Mill and Aristotle argue, it is constituted by activities of many different sorts, which cannot be rendered commensurable on any quantitative scale. Already, then, there is something very important about the good human life that Benthamism does not capture.

But there is an even greater problem: Pleasure is simply not normatively reliable, for reasons that we have already anticipated in talking about "positive" and "negative" emotions. Some pleasures are bad, namely those that are closely associated with bad activities and that, often, reinforce the tendency to engage in those activities. Rich people have pleasure in being ever richer, and lording it over others, but this hardly shows that redistributive taxation is incorrect. Racists have pleasure in their racism, sexists in their sexism. In general, bad people have pleasure in their bad behavior. The more philosophical among welfarist economists have been quick to notice this problem. John Harsanyi-after excluding pleasures based upon incorrect and/or incomplete information from the social welfare functionfeels the need to exclude, as well, pleasures that he calls "sadistic or malicious," a notion that he unpacks further by emphasizing that a Kantian notion of human equality is tempering his commitment to Utilitarianism. Bad pleasures, for him, will be those that insist on subordinating others and in other ways failing to respect their human dignity and equality. ${ }^{25}$ Analyzing Harsanyi's argument, I have argued that at this point he uses independent moral notions - the notions of dignity and equality-

\footnotetext{
25 John Harsanyi, "Morality and the Theory of Rational Behaviour," in Amartya Sen and Bernard Williams, eds., Utilitarianism and Beyond. (Cambridge: Cambridge University Press, 1982), 39-62.
} 
to constrain his welfarism; thus, his view cannot be seen as a pure welfarist view. ${ }^{26}$ It is plausible, as a guide to public policy, precisely because it imports these independent moral notions and refuses to follow Bentham all the way.

We see here another place where Mill wisely departs from Bentham. In his great work The Subjection of Women (1869), he makes it perfectly clear that men take great pleasure in subordinating women, because this helps them to feel superior, to have a pliant servant around the house, and so forth. But then, when reckoning up the gains to society that sex equality would bring with it, Mill does not even pause to consider or reckon up on the cost side the pain that men will surely be caused by this abrogation of their unearned privileges. He just assumes, anticipating Harsanyi, that these unjust pleasures do not count in the social welfare function.

Another problem, which we have already encountered in talking about Wordsworth and about positive and negative emotions, is that some valuable activities are not accompanied by pleasure. Aristotle's example is Wordsworthian (perhaps the source for Wordsworth's poem): the courageous warrior who faces death in battle for the sake of a noble end. It is absurd to say that this person is pleased at the prospect of death, says Aristotle. Indeed, the better his life is, the more he thinks he has to lose, and the more pain he is likely to feel at the prospect of death. Nonetheless, he is acting in accordance with excellence and is aware of that; and so, he is still happy, in Aristotle's sense. This just goes to show, says Aristotle, that pleasure does not always go along with the activities that comprise happiness, only most of the time.

Wordsworth goes yet further: He emphasizes that the experience of risk and suffering deepens the personality, increasing compassion for others and making a person "more skilful in self-knowledge." In the Rhetoric, discussing compassion, Aristotle agrees: He points out that people who have never faced their own weaknesses, and who think, optimistically, that they are not very likely to suffer, tend to have little compassion for the sufferings of others; he calls this a hubristike diathesis or "overweening disposition." ${ }^{27}$ Rousseau develops this insight in Emile, talking about the nobles of France, who fail in sympathy for the poor because they think they are above the common sufferings of human life. ${ }^{28}$ Rousseau's proposed remedy for this problem is that education should focus on the inculcation of painful emotion in the form of pitié, compassionate pain at the sufferings of others. He believes that it will not be easy for young Emile to learn that emotion, because, like all children, he wants to feel good. But sadness must be dinned into him by repeated teaching about the common predicaments of human life, the bodily frailty we share with others, the countless other miseries to which human life is subject. This lesson is reinforced and deepened by actual suffering: the deaths of animals that the child loves, for example.

Not implausibly, Rousseau connects this teaching with ultimate happiness, in the sense of flourishing life: for he thinks that there can be no happiness in society

\footnotetext{
${ }^{26}$ Nussbaum, Women and Human Development (New York: Cambridge University Press, 2001), chapter 2 .

${ }^{27}$ Aristotle, Rhetoric, II.5.

${ }^{28}$ Rousseau, Emile, ou de l'éducation, book IV.
} 
where there is hierarchy and injustice, and there can be no justice without a common sentiment of suffering about the human predicaments. To the extent that privileged groups live a charmed life and insulate themselves from the sufferings of the poor, everyone is missing out on happiness, since they are all living in a bad unjust world. Sponging off the misery of others may feel good, but it is not happiness, for Rousseau or any of the ancient thinkers whom he follows, since they think of happiness, with Aristotle, as living a flourishing life. The teaching of painful compassion is the beginning of social change and of the possibility of real happiness. "Thus from our weakness," he writes, "our fragile happiness is born."

Rousseau's problem would appear to be common in today's United States, where people used to a high standard of living fail to consider and sympathize with the plight of those who do not enjoy such happy lives. Candace Clark's wonderful book Misery and Company, a sociological study of American attitudes to sympathy and compassion, shows that most Americans do not have compassion for the poor, because they believe that the poor brought their misery on themselves. Indeed, they are more sympathetic with people who get stuck in traffic jams! ${ }^{29}$

Another study that should give one pause is the study of adolescent males by Dan Kindlon and Michael Thompson, in their excellent book Raising Cain. ${ }^{30}$ They show that the education of a young male in America is very likely to include the teaching that "real men" are above suffering. They should never feel and certainly should never admit to feeling, fear, pain, and weakness. The consequence of this deformed expectation, Kindlon and Thompson argue, is that these boys come to lack an understanding of their own vulnerabilities, needs, and fears, weaknesses that all human beings share. They lack even a language in which to characterize their own inner world, and they are by the same token clumsy interpreters of the emotions and inner lives of others. This emotional illiteracy is closely connected to aggression, as fear is turned outward, with little real understanding of the meaning of aggressive words and acts for the feelings of others. We see too many such males in American public life, and it is likely that other nations have similar problems. We should, therefore, place greater emphasis on the dangers of the hubristic disposition and, in consequence, on Rousseauian virtues that involve acknowledging one's weakness and vulnerability and reflecting on one's own experiences of loss and suffering.

Strategies are linked to diagnoses. Martin Seligman's diagnosis of Americans is that they are too anxious and unhappy, and so he proposes a public policy focus on happiness in part as a corrective. One might have doubts here. An alternative diagnosis of the American psyche would be that many Americans cannot stand to be unhappy, cannot stand to grieve, and cannot stand to look at poverty or the real damages of war. One could argue that this is a larger problem than the problem of excessive unhappiness. Does Seligman's positive psychology risk pushing already hubristic Americans in the direction of even greater hubris?

We all have our own sense of what the deeper problems are. But here I call George Orwell to my aid. In Nineteen Eighty-Four, he imagines the world of the

\footnotetext{
${ }^{29}$ Candace Clark, Misery and Company (Chicago: University of Chicago Press, 1997).

${ }^{30}$ Dan Kindlon and Michael Thompson, Raising Cain: Protecting the Emotional Life of Boys (New York: Ballantine Books, 1999).
} 
future as marred by an absence of deep pain and grief, a loss of the sense of tragedy. "Tragedy, [Winston] perceived, belonged to the ancient time ... Such things, he saw, could not happen today. Today there were fear, hatred, and pain, but no dignity of emotion, or deep or complex sorrows." Now, it is a long story to show how this absence of deep grief is connected to the politics of the novel. But let me venture to suggest that today's America is all too much like Winston Smith's Oceania in that respect: We do not connect to one another in Rousseau's way, through the sense of tragedy; instead, we connect through the desire for mastery and completeness, which is all too often connected to a narcissistic indifference to the sufferings of others. Pain and loss, acknowledged and thoroughly experienced, rather than pushed away or deflected into aggression, can help us grow "more compassionate, ... more skilful in self-knowledge," as Wordsworth says.

\subsection{Adaptation}

One normative worry that has already received a good deal of notice in the literature about subjective states and public policy is the phenomenon of adaptation: People's preferences adjust to what they know or can expect. Amartya Sen has shown that this happens even at the level of physical health: Women who are chronically malnourished and who are taught that they have no right to demand anything following the death of a husband report their heath status as good or fair, despite the evident presence of many diseases. Jon Elster makes the equally important point that people who were not brought up to think of themselves as equal citizens with a full range of citizens' rights will not report dissatisfaction at the absence of equality-until a protest movement galvanizes awareness. Feudalism went on for centuries without such a protest movement, sexism far longer. ${ }^{32}$ Empirical work on women shows that they often report satisfaction at having less education than males, because that is what they are brought up to think is right and proper. ${ }^{33}$ So deferring to the subjective experience of pleasure or satisfaction will often bias the social inquiry in the direction of an unjust status quo.

\subsection{The choice of lives}

Seligman's "positive psychology" and the ancient Greek tradition (along with their heir, J. S. Mill) agree in a limited normative criticism of Benthamism: Namely, they agree that a life with feeling alone and no action is impoverished. So, they agree that a person who sits around doing nothing, or even just counting blades of grass, or a person plugged into Robert Nozick's "experience machine" that generates pleasant experiences, is not living a life of the sort we should try to promote, however pleased that person feels. But there are many further questions once one gets clear

\footnotetext{
31 See my "The Death of Pity: Orwell and American Political Life," in On Nineteen Eighty-Four: Orwell and Our Future, ed. A. Gleason, J. Goldsmith, and M. Nussbaum (Princeton: Princeton University Press, 2005), 279-299.

32 I discuss Elster's feudalism example with reference to sexism in Women and Human development chapter 2, where I also give comprehensive references to Sen's treatment of this question.

33 See Jasodhara Bagchi, Loved and Unloved: The Girl Child in the Family (Kolkata: Stree, 1997).
} 
about that. First of all, I am not even clear that Seligman has taken a position on Mill's famous claim that it is better to be Socrates dissatisfied than a pig satisfied. He clearly thinks it is better to be Socrates satisfied than a pig satisfied, but Socrates probably had few nice-feeling emotions and substantial pain, so what should we say about that comparison and the choices of lives that we might make after thinking about it?

What I'm interested in, though, is a slightly different question, absolutely central to the Greeks and Romans, and to their classifications of virtues, and on which they disagree a good deal. There are quite a few types of worthwhile action, and some of them are riskier than others. Should one, then, choose a career that minimizes the risk of reversal and suffering? And should one urge others to choose such lives? If that aim makes sense, they all agree, one will probably choose a contemplative intellectual life. Contemplation is something that one can do under more or less all circumstances: if one is in prison, if one is poor, if one has no friends or family. Other sorts of lives require more specialized external conditions: A life of political action, for example, requires free birth, citizenship, friends, and at least some money. The life of a person who cares for family will be blasted if they all die or if one proves to be childless. So should one rank those lives below the contemplative life?

Now the Greeks exaggerate, here, the non-riskiness of contemplation. Aristotle, taking issue with that familiar picture, noted that it is ridiculous to suppose that someone who is being tortured can go on thinking well, and so, the picture of the sage thinking high-minded thoughts while being tortured on the wheel has something unrealistic about it. But still, they have a point, which I shall make with an example.

In 1996, I had occasion to spend some time at St. Andrews University in Scotland. I was, therefore, involved in the commencement and honorary-degree ceremonies, and I met the people who were being honored. The two men I shall contrast both had worthwhile lives, worthy of public honor, and they were receiving that honor. But they were very differently placed with respect to positive emotion and happiness. As they stood side by side on the stage, and as, later, I talked with them at various dinners and garden parties, I ruminated on this difference. One of the men was John le Carré, whose real name is David Cornwell. David Cornwell was a very happy man. ${ }^{34} \mathrm{He}$ was relaxed and genial, gentle, and funny. It was clear not only that he felt proud of his achievement but also that he felt in control of his ongoing activity. He loves writing-indeed, he lives in a very remote spot in Cornwall and rarely travels, so that he can write all the time. And nothing, and nobody, disturbs him. He has a lovely wife, also genial and funny, and he clearly enjoys living with her company and that of his books. ${ }^{35}$ Of course old age, illness, and death will disrupt that happiness eventually, but in 1996, he was the very image of the contemplative life and its rich human satisfactions.

\footnotetext{
34 Born in 1931, Cornwell is still healthy and productive as I write this footnote to the revised version, one day after his eightieth birthday (October 19, 2011).

35 And she too is still doing well as of October 20, 2011, as they near their fortieth anniversary.
} 
Side by side with him on the podium was John Hume, the Northern Irish politician who won the Nobel Peace Prize with David Trimball in 1998. In 1996, however, there was no peace. Things were going extremely badly, and it was plausible to think that everything Hume had worked for all his life was out the window. He had even been rudely dumped by his own party. John Hume was not a happy man. His face was like a tragic mask. He hardly spoke to a soul. He stood around at the garden parties as if he had no idea where he was. He stood up on the stage to be honored, but no glint of happiness appeared on his face. (And when you think about his life, consider that he might have died the next day, before things began to go better, before the Prize, before his lauded retirement from politics in 2004, at which time he was praised even by Ian Paisley, before the astounding reconciliation of Ian Paisley and Gerry Adams, etc.) ${ }^{36}$

That is really what the ancient debate is about: Should one pay attention to the risk of ending up in a miserable condition, all one's projects smashed, when one makes one's choice of life? Or should one focus only on the commitments and values one believes important, and follow those whatever risks they entail? The ancient thinkers did not believe that it was optional which valuable goals one pursued. So, the ones who believe that politics is part of the human good thought that its riskiness was no good argument against it: one has an obligation to pursue it, come what may. It is very moving, again, to read Cicero's letters on that point, for he repeatedly says that in losing Tullia and the Roman Republic he has lost the two things that give life meaning; and yet, he continues to exhort his son and his friend tirelessly to the political life and to insist that even the philosopher is contemptible if he does not incur risk for the sake of his country.

Benthamism, of course, gives utterly different advice: Follow the pleasant and avoid the painful-although, as Mill observes, if one takes seriously the fact that the goal is not just one's own utility, but the greatest pleasure of the greatest number, then one will be bound to notice that in the "present defective condition of society," the person who pursues that goal energetically is in for a lot of pain. Mill thinks that in a good society this would not be so, but that, in our present defective one, the good person should make the risky choice. He knows that getting from the defective one to the good one is a difficult struggle, involving a radical overhaul of education and public culture, the reason for his great interest in Auguste Comte's proposal for an altruistic "religion of humanity." That, however, is Mill, and contemporary Benthamism has no such altruistic thoughts, so far as I can see, and no such critical diagnosis of our present social condition as defective to the extent that individual and universal well-being are badly aligned.

If we now turn to Seligman's somewhat richer normative conception, it would appear that his "positive psychology" gives the following advice: To the extent that a career offers secure prospects of pleasant feeling and still contains some valuable activity, that career is to be preferred to the career that has a large risk of reversal and misery. In other words, do not go into politics, especially in Northern Ireland,

\footnotetext{
${ }^{36}$ In October 2011 Hume is still prospering at the age of seventy-five. Meanwhile he has won the Gandhi Peace Prize and the Martin Luther King award; he is the only person in history to have received all three of these major peace awards. In 2010 he was voted the greatest person in Ireland's history, in a poll conducted by the national broadcaster RTE.
} 
and perhaps not in America either! Probably all of us in the academy have given ourselves some such advice, or we would not be in tenured positions in universities, that safest of careers. But I don't think that this advice is good as a general thing. With Cicero, I think that there are some values that need to be fought for and that each of us ought to do some fighting and incur some risk, to fight for what is important, even if we are in the protected precincts of the academy. And if the world were such that everyone were as risk-averse as most academics by nature are, it would be a horrible place, with much less justice in it, even, than it now has. So, some, indeed many, good people must make the riskier choices of lives, or we all will end up with nothing worth living for.

Thus, while I enjoyed the company of David Cornwell more than that of John Hume, and while I found in David Cornwell a kindred contemplative happy spirit, I admired John Hume more and criticized myself for not being more like him. Similarly, when I am in India working with development activists, I often feel awed and humbled by them, because they are out there in the trenches, risking bodily health, contentment, and life itself, while I'm sitting in a beautiful building at a new computer, writing. One of India's most admired activists for women's issues, the creative NGO founder Viji Srinivasan, died in 2005, in her late fifties, of respiratory collapse, on a train bound from Delhi to Chennai, because the harsh conditions in which she worked, running a women's organization in rural Bihar, had ruined her health. I have not made such choices: Indeed, whenever I travel, I ask for time to go to the gym, and I choose a good hotel. My excuse to myself is that I would be very bad at what they do and that what I do is not altogether irrelevant to the pursuit of justice. But it is an uneasy excuse, and I honor them for their choices.

Public policy should make room for, and honor, commitments that are in their very nature fraught with risk, pain, and difficulty, especially commitments to fighting for social justice, as not optional but mandatory parts, in some form, of the good life of any human being. A society that thinks this way will make different policy choices: It will favor, for example, as I do, a program of compulsory national service for all young people, in which they will learn to care for elderly people and do other valuable and unpleasant tasks. Where education is concerned, it will follow Mill and Comte in placing a great deal of emphasis on altruism and a sense of shared identity. Public rhetoric, public art, and public festivals will all be constructed with this goal in mind. ${ }^{37}$ Young people in America are all too often encouraged, instead, to follow pleasure and to avoid the risk of unhappiness. To the extent that such recommendations are successful, our country is the poorer.

\subsection{Aggregation}

Benthamism already aggregates in a questionable way, by funneling all the states associated with diverse activities into a single quantitative calculus. There is, however, another type of aggregation to consider: its aggregation across persons.

\footnotetext{
37 See my current book in progress, Political Emotions: why love matters for justice (Cambridge, MA: Harvard University Press, to appear in 2013); for two portions of the book already in print, see "Reinventing the Civil Religion: Comte, Mill, Tagore," in Victorian Studies 2011; and "Teaching Patriotism," in University of Chicago Law Review 2011.
} 
For the Benthamite, we are to strive to produce the greatest net balance of pleasure over pain for the greatest number. This "sum-ranking," as Amartya Sen and Bernard Williams aptly call it, ${ }^{38}$ seems to treat all people equally: As Bentham says, "each to count for one, and none as more than one." Looked at more closely, however, this approach prevents us from providing a minimum floor of dignity and decent life beneath which no person is to be pushed. The exceeding pleasure of a large number can justify giving a small number a very miserable life. This is yet one more reason to doubt the facile equation of pleasure with happiness. But this criticism of Utilitarianism is so well-known and so often-discussed that I shall pursue it no further here.

\section{Pursuing an objective list: some misunderstandings}

In one of the clearest, most rigorous, and most interesting discussions of the subjective-state approach, Paul Dolan and Mathew P. White contrast it with an "objective-list" approach, of which I am named as an exemplar. ${ }^{39}$ Their article, however, betrays some misunderstandings, and it seems like a good occasion to correct them here.

In Women and Human Development, Frontiers of Justice, ${ }^{40}$ and numerous articles, particularly central being the 2003 article "Capabilities as Fundamental Entitlements," 41 I argue that a good way of thinking about some central political principles that can be the basis for constitutional guarantees is to think of them as a list of "capabilities" or opportunities for functioning, which include both the internal education for that functioning and the provision, and protection, of suitable external circumstances for actually choosing the functioning. My list of capabilities is given in "Appendix 2."

Dolan and White make the objection that this conception is "paternalistic," insofar as it "may be left to policy makers" to decide what well-being is for everyone, and then to "impos[e]" it. While this objection might possibly be brought against some versions of the objective-list approach, it surely cannot be brought against mine. Indeed, despite being pleased at being cited in this very good article, I am less than pleased by the fact that the authors appear not to have read chapter 1 of the book they cite (Women and Human Development), which is all about the ways in which I would answer the charge of paternalism, or chapter 2 either, in which I fault some objective-list accounts for being insufficiently sensitive to desire and show what role desire plays in my idea of justification. (The book has only four chapters,

\footnotetext{
38 See "Introduction," in Utilitarianism and Beyond (Cambridge: Cambridge University Press, 1993).

39 Dolan and White, "How can measures of subjective well-being be used to inform public policy?" draft.

40 Frontiers of Justice: Disability, Nationality, Species Membership (Cambridge, MA: Harvard University Press, 2006).

41 Feminist Economics 9 (2003), 33-59. See also "On Hearing Women's Voices: A Reply to Susan Okin," Philosophy and Public Affairs 32 (2004): 193-205. And see, now, Creating Capabilities: The Human Development Approach (Cambridge, MA: Harvard University Press, 2011).
} 
chapters 3 and 4 being less pertinent to the question they pose.) It is difficult to summarize briefly the results of such lengthy discussions, but let me try. ${ }^{42}$

First of all, the nature of my project must be described: I am not trying to provide an account of well-being for all public purposes. I am trying to provide an account of a central group of very fundamental entitlements, those without the securing of which no society can lay claim to basic justice. The account is closely linked to constitution making and to the idea of fundamental constitutional rights. ${ }^{43}$

Second, the account is explicitly said to be, in John Rawls's sense, a political rather than a comprehensive account ${ }^{44}$ : It is deliberately narrow and partial, confining itself to a core group of entitlements that can, it is argued, become the object of an overlapping consensus among people who have very different comprehensive views, religious and secular, of the meaning and purpose of human life.

Third, the items on the list, these key political goals, are, crucially, capabilities, not actual functionings. The point here is to leave room for choice. A person who has the right to vote (and really can go out and vote, with no subtle impediments or discrimination) may always choose not to vote; a person who has access to adequate health care can always choose an unhealthy lifestyle. A person who has the freedom of religion may decide to have nothing to do with religion. The only place where my conception is paternalistic, imposing a specific mode of functioning, is when we are speaking of children. Here, I would impose compulsory primary and secondary education, and I would also allow the state to intervene in parental health care choices where the health and life of children is at risk. But this is hardly controversial.

It seems obvious that people may endorse a given item as a capability while believing that, for themselves, it would be quite wrong to function in that way. The Amish believe that it is wrong to vote, but they can happily endorse the right to vote as a fundamental entitlement of all citizens in a pluralistic society. A person whose personal choice is to live an extremely unhealthy lifestyle and never go to the doctor can happily endorse a decent national health care program: Nobody is forcing her to use it, and she realizes that fellow citizens, whom she respects, do not share her lifestyle preferences. Even the most militantly antireligious people in the U. S. do not applaud the policies of nations that suppress religion; they are happy to defend religious liberty.

Fourth, even at the level of specifying the items on the list, the conception leaves much room for the democratic political process to play itself out. A free speech right, for example, is never fully specified in the founding document itself: Its contours become clearer over time through a combination of legislative and judicial

\footnotetext{
42 All of these points are made in WHD, in Frontiers, and in "Capabilities as Fundamental Entitlements," in more or less identical form, although not in the same order. Dolan and White may of course not be satisfied by what I say, but they should at least engage it.

43 See Nussbaum, “Constitutions and Capabilities: 'Perception' Against Lofty Formalism," Supreme Court Foreword 2006, Harvard Law Review 121 (2007), 4-97.

44 See Rawls, Political Liberalism (New York: Columbia University Press, expanded paper edition 1996). I discuss my reasons for endorsing political liberalism in "Perfectionist Liberalism and Political Liberalism," Philosophy and Public Affairs 39 (winter 2011), 3-45.
} 
action. Within limits, different societies may legitimately do this differently, in accordance with their different traditions.

Fifth, the list includes many of the major liberties of choice without which meaningful choice is not possible. If a society does not commit itself to the right of free speech, the right to free association, the freedom of conscience, all in a way that entrenches these entitlements, setting them beyond the vicissitudes of majority voteas, for example, in a constitution somewhat difficult to amend - it is showing, I would argue, deficient concern for human choice and liberty. In this sense, "paternalism" (if we should use that name for constitutional rights that are protected beyond majority whim) is not opposed to liberty of choice, but essential for its stability.

Sixth, the list is ultimately justified only through a complex process that involves consulting informed desires of certain types. I shall not elaborate further here, since the entire second chapter of Women and Human Development is required to give those conditions.

Seventh, the list is a template for persuasion, not for forcible implementation. If any country is going to put these items into its constitution, it will be only because it has gone through some type of political process internally, for example, a constitutional convention. I am against any sort of forcible intervention in the affairs of another nation, except in the case of genocide.

I am not sure, then, where the objectionable element of paternalism is. If Dolan and White believe that the very fact of having a list of fundamental entitlements specified in a constitution entrenched beyond majority whim is an objectionable form of paternalism, they certainly do not make that argument. Nor do they make any argument trying to show that the capabilities on my list could not become the object of an overlapping consensus, as capabilities, among people who endorse very different comprehensive views of the good life.

I say nothing at all about what account of well-being should be used by administrative agencies when they are not following core constitutional mandates. But the general tenor of my account would be that whatever they do should be respectful to the plurality of comprehensive doctrines that citizens reasonably hold.

\section{The truth in subjective state analysis}

When, then, is it right to focus on subjective states, in the light of all these normative difficulties? Here, we should return to Mill. Mill, out of his long experience of depression, articulates a version of Aristotelianism that is, to my mind, slightly ahead of Wordsworth's. Wordsworth focuses so much on fine activity that he suggests that subjective feelings of pleasure do not matter at all. In his Autobiography, Mill describes himself, during his depression, as still active in accordance with a variety of good purposes. And yet his life felt empty and meaningless. Only the nourishment of poetry (prominently including Wordsworth's poetry) lifted him out of his torpor. Shortly after that, he met the love of his life, Harriet Taylor. ${ }^{45}$ We should pay attention to Mill's experience and realize that it is

$\overline{45}$ See my discussion in "Mill Between Bentham and Aristotle." 
important to treat depression, whether or not the treatment contributes to enhancing valuable activities (and usually, of course, it does). Subjective states matter greatly, and sometimes we can produce them through direct interventions, even though by and large pleasures are closely associated with activities. Public policy should certainly adopt the treatment of depression as a valuable goal, for example, and it would not do so if it followed purely Wordsworthian lines. (Indeed, my capabilities list makes room for this, making the opportunity for at least some pleasure and the relief of pain a central entitlement.)

Public policy should also focus on the mitigation of the sort of pain that is not an enrichment of the soul or a deepening of self-knowledge, and there is a lot of pain that is not conducive to anything good. If we can totally eliminate hunger and painful childhood diseases, for example, we should do that. We should also strive to eliminate child sexual abuse, domestic violence, and rape, all of which are pains that seem to have no positive educative function. When people have a painful illness that cannot be cured, palliative treatment should be supported by a decent scheme of national medical insurance, and this same decent scheme should adequately cover the treatment of depression and other mental illnesses. The badness of pain should be a central consideration in end-of-life care and in the discussion of physician-assisted suicide.

Beyond this, Dolan and White make sensible recommendations in the area of curtailing environmental pains, such as noise pollution. We can add that nuisance law, as it has evolved, is a sophisticated set of strategies for dealing with the distress that people may cause to other people without direct physical assault, and such laws have a valuable social purpose. ${ }^{46}$ To endorse these proposals, we do not need to be Benthamites, we do not need to endorse Bentham's unitary view of pleasure, and we certainly do not need to equate pleasure with happiness.

Indeed, we had better not be Benthamites, or else we are likely to use such insights in ways that dangerously subordinate and oppress. To some people, the distress caused by the presence of a homosexual couple next door is just as acute as the distress caused by the presence of a running sewer next door. The law, however, has learned to distinguish between an actual physical distress directly caused by a bad smell and the type of distress that is mediated by imagining what people are doing behind closed doors. For Bentham, there is no such difference: Pleasures and pains vary only in intensity and duration. So, if we are to use the insight that Dolan and White provide us, and, centrally, the insight that Mill's Autobiography provides us, we had better have more adequate conceptions of pleasure and pain than Bentham did, and we had better have a firm grasp on moral principles (such as the protection of privacy and choice) that are independent of pleasure and pain, and whose protection, indeed, has always proven painful to nosy people, which is to say most of the people who are around. (Once again, Mill points the way to wise policy choices, by defending personal liberty and by distinguishing a genuine harm from a "purely constructive injury" in which one feels displeasure simply as a result of imagining something one does not like). ${ }^{47}$

\footnotetext{
46 See my Hiding From Humanity: Digust, Shame, and the Law (Princeton: Princeton University Press, 2004), chapter 3.

47 For the implications of these ideas for the rights of gays and lesbians, see my From Disgust to Humanity: Sexual Orientation and Constitutional Law (New York: Oxford University Press, 2010).
} 
In short, the appeal to subjective well-being, as currently used in the psychological literature, is not utterly useless, but at present, it is so riddled with conceptual confusion and normative naïveté that we had better pause and sort things out before going any further.

Acknowledgments This paper is a lightly revised version of a paper originally published in the Journal of Legal Studies 37 (2008), and in Law and Happiness, ed. Eric A. Posner and Cass R. Sunstein (Chicago: University of Chicago Press, 2010), 81-114.

\section{Appendix 1: Wordsworth's poem}

\section{Character of the happy warrior}

Who is the happy warrior? Who is he

That every man in arms should wish to be?

-It is the generous Spirit, who, when brought

Among the tasks of real life, hath wrought

Upon the plan that pleased his boyish thought:

Whose high endeavours are an inward light

That makes the path before him always bright;

Who, with a natural instinct to discern

What knowledge can perform, is diligent to learn;

Abides by this resolve, and stops not there,

But makes his moral being his prime care;

Who, doomed to go in company with Pain,

And Fear, and Bloodshed, miserable train!

Turns his necessity to glorious gain;

In face of these doth exercise a power

Which is our human nature's highest dower:

Controls them and subdues, transmutes, bereaves

Of their bad influence, and their good receives:

By objects, which might force the soul to abate

Her feeling, rendered more compassionate;

Is placable-because occasions rise

So often that demand such sacrifice;

More skilful in self-knowledge, even more pure,

As tempted more; more able to endure,

As more exposed to suffering and distress;

Thence, also, more alive to tenderness.

-'Tis he whose law is reason; who depends

Upon that law as on the best of friends;

Whence, in a state where men are tempted still

To evil for a guard against worse ill,

And what in quality or act is best

Doth seldom on a right foundation rest,

He labours good on good to fix, and owes

To virtue every triumph that he knows:

-Who, if he rise to station of command, 
Rises by open means; and there will stand

On honourable terms, or else retire,

And in himself possess his own desire;

Who comprehends his trust, and to the same

Keeps faithful with a singleness of aim;

And therefore does not stoop, nor lie in wait

For wealth, or honours, or for worldly state;

Whom they must follow; on whose head must fall,

Like showers of manna, if they come at all:

Whose powers shed round him in the common strife,

Or mild concerns of ordinary life,

A constant influence, a peculiar grade;

But who, if he be called upon to face

Some awful moment to which Heaven has joined

Great issues, good or bad for human kind,

Is happy as a Lover; and attired

With sudden brightness, like a Man inspired;

And, through the heat of conflict, keeps the law

In calmness made, and sees what he foresaw;

Or is an unexpected call succeed,

Come when it will, is equal to the need:

- He who though thus endued as with a sense

And faculty for storm and turbulence,

Is yet a Soul whose master-bias leans

To homefelt pleasures and to gentle scenes;

Sweet images! Which, wheresoe'er he be,

Are at his heart; and such fidelity

It is his darling passion to approve;

More brave for this, that he hath much to love;-

'Tis, finally, the Man, who, lifted high,

Conspicuous object in a Nation's eye,

Or left unthought-of in obscurity,-

Who, with a toward or untoward lot,

Prosperous or adverse, to his wish or not-

Plays, in the many games of life, that one

Where what he most doth value must be won:

Whom neither shape nor danger can dismay,

Nor thought of tender happiness betray;

Who, not content that former worth stand fast,

Looks forward, persevering to the last,

From well to better, daily self-surpast:

Who, whether praise of him must walk the earth

For ever, and to noble deeds give birth,

Or he must fall, to sleep without his fame,

And leave a dead unprofitable name-

Finds comfort in himself and in his cause; 
And, while the mortal mist is gathering, draws

His breath in confidence of Heaven's applause;

This is the happy warrior; this is he

That every man at arms should wish to be.

\section{Appendix 2: The central human capabilities}

1. Life. Being able to live to the end of a human life of normal length; not dying prematurely or before one's life is so reduced as to be not worth living.

2. Bodily Health. Being able to have good health, including reproductive health; to be adequately nourished; to have adequate shelter.

3. Bodily Integrity. Being able to move freely from place to place; to be secure against violent assault, including sexual assault and domestic violence; having opportunities for sexual satisfaction and for choice in matters of reproduction.

4. Senses, Imagination, and Thought. Being able to use the senses, to imagine, think, and reason - and to do these things in a "truly human" way, a way informed and cultivated by an adequate education, including, but by no means limited to, literacy and basic mathematical and scientific training. Being able to use imagination and thought in connection with experiencing and producing works and events of one's own choice, religious, literary, musical, and so forth. Being able to use one's mind in ways protected by guarantees of freedom of expression with respect to both political and artistic speech, and freedom of religious exercise. Being able to have pleasurable experiences and to avoid non-beneficial pain.

5. Emotions. Being able to have attachments to things and people outside ourselves; to love those who love and care for us, to grieve at their absence; in general, to love, to grieve, to experience longing, gratitude, and justified anger. Not having one's emotional development blighted by fear and anxiety. (Supporting this capability means supporting forms of human association that can be shown to be crucial in their development.)

6. Practical Reason. Being able to form a conception of the good and to engage in critical reflection about the planning of one's life. (This entails protection for the liberty of conscience and religious observance.)

7. Affiliation. A. Being able to live with and toward others, to recognize and show concern for other human beings, to engage in various forms of social interaction; to be able to imagine the situation of another. (Protecting this capability means protecting institutions that constitute and nourish such forms of affiliation and also protecting the freedom of assembly and political speech.)

$B$. Having the social bases of self-respect and non-humiliation; being able to be treated as a dignified being whose worth is equal to that of others. This entails provisions of non-discrimination on the basis of race, sex, sexual orientation, ethnicity, caste, religion, and national origin.

8. Other Species. Being able to live with concern for and in relation to animals, plants, and the world of nature. 
9. Play. Being able to laugh, to play, and to enjoy recreational activities.

10. Control over one's Environment.

A. Political Being able to participate effectively in political choices that govern one's life; having the right of political participation, protections of free speech and association.

B. Material Being able to hold property (both land and movable goods) and having property rights on an equal basis with others; having the right to seek employment on an equal basis with others; having the freedom from unwarranted search and seizure. In work, being able to work as a human being, exercising practical reason and entering into meaningful relationships of mutual recognition with other workers. 